JOURNAL OF SECURITY AND SUSTAINABILITY ISSUES

ISSN 2029-7017 print/ISSN 2029-7025 online

2021 Volume 11

https://doi.org/10.47459/jssi.2021.11.22

\title{
PENITENTIARY SPACE THROUGH THE EYES OF PRISONERS - AN EXAMINATION OF PRISON LETTERS. THE RELEVANCE OF PLACE
}

\author{
Slawomir Grzesiak \\ Academy of Justice, 50 Wiśniowa Street, 02-520 Warsaw, Poland \\ E-mail: slawomir.grzesiak@swws.edu.pl
}

Received 13 October 2020; accepted 10 April 2021; published 30 June 2021

\begin{abstract}
The aim of the research was to analyse letters written by prisoners so as to discover what the penitentiary space means to them. The practical goal was to show the usefulness of employing epistolography in assessing the quality of social and living conditions and to evaluate the quality of penitentiary practices in the context of prisoners' needs, as well as to unmask the hidden re-education programme. The article is based on the results of the content analysis of 26 anonymised letters written by prisoners who for the first time serve a sentence in Polish closed regime prisons. The collected research material was subjected to a framework analysis supplemented by an emergent technique. The analysis of prison letters indicates a generally critical assessment of the quality of the practices carried out and their accuracy in relation to the prisoner's rehabilitation needs. The letters reveal also the existence of a hidden re-education programme. The use of the epistolary corpus in the description of the penitentiary space may result in the improvement of the current penitentiary methods. A thorough analysis of prison letters indicate areas that require change or the application of specific solutions that may contribute to the rationalization of penitentiary practices.
\end{abstract}

Keywords: imprisonment; penitentiary rehabilitation; re-education, security; Prison Service

Reference to this paper should be made as follows: Grzesiak, S. 2021. Penitentiary space through the eyes of prisoners - an examination of prison letters. the relevance of place. Journal of Security and Sustainability Issues, 11, 255-264.

https://doi.org/10.47459/jssi.2021.11.22

JEL Classifications: Z00

Additional disciplines: penitentiary, prisoners, re-education

\section{Introduction}

The legal status of prisoners is determined by their rights and obligations. From the re-educational point of view, one of the most important rights is the ability to keep in touch with the outside world (Journal of Laws of 2020). Depending on the type of penitentiary isolation (Journal of Laws of 2020; Kalisz 2015, 67-82), the possibilities of establishing and maintaining contacts and social ties with the external environment are limited. As the contact with the external environment is constricted, all kinds of written forms - requests, complaints, letters, diaries, prison literature and other types of writing remain very popular.

In view of the above, the writings of people deprived of freedom constitute an interesting source of knowledge about the penitentiary space, especially in the context of conducting personal identification tests in conditions of prison isolation (Poklek 2017, 41-57), as well as in the context of the security of the penitentiary unit, and in a broader sense, also in the context of public safety (Kołtun, Kośmider 2019). Prisoners' letters may be useful in diagnosing the social climate of an institution (Pytka 2005, 164; Nowak 2017, 105-117) and in conducting socially engaged research on the spatially conditioned agency of a person, their readiness to change, as well as 
all those imponderable elements of the penitentiary space which can be included in the phrase 'the theatre of social life' (Goffman 2011; Szczepanik 2015). As a consequence, undertaking this type of scientific research and the use of epistolography in the description of penitentiary space may result in the optimisation of the current methods of conducting penitentiary work.

\section{Place as a space of re-education - the framework of theoretical analysis}

Penitentiary work (Machel 2003, 23), and, in particular, its narrow aspect relating to re-education activities undertaken towards prisoners and aimed at adapting them to life in society after serving a sentence of imprisonment, is carried out with various results, as is evidenced by the growing criminal recidivism rate (Grzesiak 2019). A penitentiary unit is a place where various types of re-education activities take place, but their results are sometimes contradictory to their authors' intentions (Przybysz 2011, 180-192; Szczepanik 2015). This hidden re-education programme, which in its extreme form may lead to prison socialization that consolidates the process of prisonization and educates prisoners to live in prison rather than in society, is one of the factors hindering the process of penitentiary rehabilitation. In this approach, the penitentiary unit becomes a space for dialogue (Mendel 2018; Copik 2013, 179-189), a space for shaping identity and organizational culture.

The study adopts Toporow's perspective, which indicates a bipolar correlation between the text and the space: "the text is spatial (i.e. it has the feature of spatiality, it fits into the "real" space, as it is true in the majority of the messages that make up the basis of human culture), and space is a text (i.e. space as such can be understood as a message)' (Toporow 2003, 15). Such an approach determines the use of the theory of symbolic interactionism and the concept of place pedagogy and lays down the context for further considerations.

From the point of view of symbolic interactionism (Siemaszko 1993, 265-272; Bernasiewicz 2011; Hałas 2006), it is important to understand the motives, actions, relationships and definitions of the situation in which prisoners find themselves, as well as to pay attention to the subjective meanings that senders attribute to reality and how they reconstruct it (Blumer 2009). The authors of letters are treated as active subjects who give meaning to their narratives transmitted through letters beyond the prison walls. Thus, it is prisoners who shape the way the addressees of their letters perceive the penitentiary space.

This view is supplemented by Mendel's concept of place pedagogy, which shows the existence of a mutual relationship between the person and the place, where space is an area of constant exchange of experiences and information, significant for the processes of learning about a place and its development, as well as shaping identity and social relations between individuals, groups or institutions (Mendel 2006). These considerations refer to the analysis of the penitentiary space constituted by total isolation where processes such as adaptation techniques, assigning meaning, making places understandable, creating social bonds and understanding a place as a space for change may take place.

The justification for adopting this particular theoretical framework lies in the interpretative dimensions that emerged from the collected research material and the way the authors of letters assign meanings to various aspects of the penitentiary space, the subjective assessment of which may affect their readiness to change. At the same time, looking at the penitentiary facility as described by prisoners allows for the discovery of a hidden penitentiary programme in this specific type of a narrative.

\section{Framing the penitentiary space - a methodological perspective}

The description of the penitentiary space as a set of imponderable elements requires determining the boundary conditions, the so-called reference framework. For the purposes of the analysis, the concept of Goffman's framework analysis was applied. According to Goffman, 'how people define what is relevant and irrelevant at a given moment determines the framework through which the given circumstances are constituted' (Silverman 2007, 88). Hence, the frame is a specific perspective which organises the human experience in a conscious or unconscious way. At the same time it is also an interpretative scheme and a scheme of action (Goffman 2010). 
Therefore, the framing process led to the selection of a limited number of threads which in turn resulted in emphasising only some aspects of the penitentiary space presented in the letters. A specific way of defining the space, its interpretation, moral evaluation, emerging emotions, and sometimes also suggestions as to further actions with regard to shaping this space were also highlighted.

The context for the research was the situation in which people deprived of liberty find themselves and the way they perceive and assess the prison as an organisation (Journal of Laws of 2019). The analyses were embedded in grounded theory and the theory of symbolic interactionism. The method of document analysis was used, which was narrowed down to the use of the content analysis technique. This way, the collected empirical material in the form of letters from prisoners can be a valuable source of knowledge about their emotions, views, opinions and the place where they serve their prison sentence, as well as about the process of their re-education. The adopted research orientation of the analysis of the prisoners' correspondence allowed for the clearly qualitative intersubjective nature of the interpretation of the collected material and made it possible to notice the complexity and multiplicity of various threads resulting from it (Szczepaniak 2012, 110).

The content analysis of the collected empirical material concerned the description of both explicit and implicit content of the letters, as considering only one perspective would be superficial and of little value. The studied material was placed in a broader context, which at the same time created the possibility of drawing erroneous conclusions beyond the explicit content of the message. The method of content analysis is not a simple inference about the material studied, the author's reading of the contents and their interpretation (Lisowska-Magdziarz 2004, 14-15). It is a multifaceted interaction between the body of knowledge on a given topic, the author's current beliefs and experiences, and their intentions leading to the creation of the text; the knowledge, experiences and beliefs of researchers. All these factors strongly influence the process of creating the message and its subsequent interpretation in the social context (Szczepaniak 2012, 86; Fiske 2009, 182; Goban-Klas 2009, 131-132).

The chosen research procedure was sequential. The first stage of the work encompassed the selection of the research material, which was anonymised correspondence of prisoners serving a sentence of imprisonment in a closed prison for the first time, who were transported between penitentiary units as part of serving a prison sentence. The research was carried out between 2015 and 2016, and its scope included the qualitative analysis of 26 letters from prisoners.

The letters were sent to two groups of recipients. The first group consisted of other prisoners, colleagues or friends from the so-called residential cell, with whom the addressee of the letter had contact at some stage of the imprisonment, therefore, due to the shared experience of being in prison isolation, the penitentiary space was known to both the sender and the addressee. The second group of recipients were family members (parents, siblings, cousins), or people close to the them (partners or friends), staying outside of the prison gates, for whom the penitentiary space is usually unknown and it is the prisoner who is responsible for creating the image of the prison isolation in the addressees' eyes.

Then, the selected correspondence was subjected to multiple readings. The analysis of the empirical material focused on what and how the prisoners wrote in the letters sent to people closest to them. This allowed to see both the intentions of the authors and some hidden elements, which is a typical measure undertaken by prisoners who are aware of censorship and correspondence control. Hence, discovering the penitentiary world presented in the letters required 'being immersed' in this world in order to be able to structure the topics discussed and their content.

The next stage of the content analysis was the development of a categorization key understood as a system of elements having common features that allow for combining them into specific groups (Lisowska-Magdziarz 2004, 54-55). The qualitative analysis of the letters made it possible to define the characteristic content and to study the sender's intentions, which required taking into account the context and circumstances of the content creation (Palska 1999, 166). The process of creating a categorization key was based on emergent technique and consisted of combining similar threads with simultaneous attempts to capture maximum thematic diversity, 
which required building categories and concepts mentioned in the analyzed content. It was also necessary to define the categories in the key to approximate the way in which they were distinguished and how they were understood by researchers. The preparation of the definition of individual key categories narrowed the scope of the composition of a given category, at the same time clarifying and justifying what is to be included in a given area and what should be rejected.

As a result, five categories were selected: place, re-educational activities, correspondence relations, feelings and emotions accompanying the place-to-person relation, and temporality. The two categories that directly related to the subject of the study concerned the assessment of the quality of organisation and work of penitentiary units and the re-education activities carried out in them. They included:

1) place - attention was paid to fragments of letters concerning the description of the place, social and living conditions, the general impression related to the organisation of the place and its evaluation, and everything that creates a penitentiary space;

2) re-education activities - the content of correspondence relating to the staff and penitentiary interactions.

Due to the extensive research material and the editorial requirements for the development of the scientific text, the remaining three categories distinguished on the basis of the analysis of the content of the prisoners' correspondence will be presented in another article. It will concern emotions, opinions and feelings experienced by prisoners during imprisonment, ways of coping with the situation of imprisonment, interpersonal relations and temporal references regarding to the past, present and future.

\section{The results of empirical research}

The paper presents the results of the analysis of the prisoners' correspondence regarding the physicality of the prison, its social and living conditions and re-education activities carried out in penitentiary units, and a specific subjective assessment of the quality of organisation and work of penitentiary units. It is the result of combining the areas of analysis with fragments of the prisoners' correspondence, thanks to which it is possible to present only fragments of the collected empirical material without the need to disclose entire letters. The analyses focused only on the excerpts of prison letters concerning the penitentiary space and the perception of the prison situation. The presented fragments were quoted in the original spelling, keeping the grammar and spelling of the manuscript, but in a way that makes it impossible to identify their authors. Each letter is given a number after the quote in parentheses. All the letters in which the indicated issues occurred were analysed. The article contains only selected, most characteristic and significant statements that correspond to each key category.

\section{The physicality of the prison}

The physicality of the prison refers to its organisation and the way its beneficiaries perceive it from the point of view of the functions that are important to them. In the case of a penitentiary unit, the most important elements relate to social and living conditions that determine the comfort and quality of prison life.

The letters show that prisoners who have already experienced imprisonment in several penitentiary units pay more attention to the social and living conditions prevailing in them and appreciate even small amenities. The letters contain a comparative analysis of prison conditions. Many letters give information on these issues, for example:

- 'We live in six in a 7-person cell in the castle, an hour of walking, the rest of the day in the cell. It is such a chic cell that makes you want to sit down, hot water all day, power doesn't piss off during the day. The food is really awesome, a fancy window view on the street, and you can see people walking. Reptiles [=prison officers] are after the bag [ $=$ okay], the receiver [=phone call] every day, no $>$ Szamak $<[=$ outcasts from the prison community belonging to the criminal subculture]. (...) The food is so good that you don't have to buy cereal. It's nice and warm in the cell, the cell looks like a room in a staff hotel. New clothes, even new blankets when you enter. I have the bottom shelf [the bottom of a bunk bed] I don't have to tidy up. The morning call at 6.00 , then I sleep even until lunch, it's peace and quiet. There is a sports hall, there are almost 
150 people in the slam (9)';

- 'As for the prison, it's not as bad as they describe. The conditions are average, but not too bad ... Cold water ..., draughts and power cuts are the biggest drawbacks for me' (14).

Interestingly, such differences in prison conditions occur despite the statutory guidelines regulating and standardizing these issues throughout Poland.

Prisoners are often positively surprised by good living conditions and standards of sanitary facilities, although access to hot water should be the norm in every penitentiary facility. 'I did not even expect it to be so good, it's 100 times better in this chokey, good food, I even had pancakes, rice, minced meat chops, I'll tell you that it's good, hot water is all the time, they do not switch off the power, change of blankets every Saturday, there's a sports hall, I go there to play football or table football, I stay in the 7-person room, there's a telly and a console' (11). The vital needs of incarcerated persons are the issues of food, being placed in a residential cell, internal order, sanitary conditions or relations with staff, hence these threads repeat many times in the analysed letters. These issues are very important for prisoners, which is confirmed by surprisingly positive and at the same time quite humorous opinions, e.g.

- 'Wish you had come with me. It's 100 times better, it makes you want to be in jail $\odot$ [...] I feel really good here. I'm happy.' (9);

- '[...] you feel here like at home' (6).

Writing about positive emotions experienced in prison is a substitute for joy, which from the perspective of people enjoying freedom may seem incomprehensible.

It should be remembered that a penitentiary unit is a specific place where the functioning of people is determined by space. It is also related to the status of prisoners and the need to ensure the safety of all prisoners and all the staff. Hence, prisons are places where detainees have limited agency, because it is the staff of the penitentiary unit that takes responsibility for prisoners in many areas of their life that in the free world they would be able to decide for themselves. A very accurate and at the same time metaphorical definition of the prison, showing all its 'isolated' complexity, is visible in a letter of one of the prisoners: 'Greetings from the land of a thousand locks and one key’ (22).

The prison community is made up of both the staff of the penitentiary unit and the prisoners residing in it. It should also be remembered that the colloquial phrase about 'being on the opposite sides of the bars' does not mean mutual hostility. Both groups create the penitentiary space, 'clashing' in discussions and conflicts over its shape, which is typical for total institutions. Conflicts or differences of opinion are inscribed in these institutions and therefore should be treated as an immanent property of the penitentiary space (Grzesiak 2015, 140-157), where 'there is a conflict of interests, views, attitudes of individuals or social groups' (Balawajder 1992, 4).

In the analysed correspondence, even negative messages regarding the assessment of the functioning of penitentiary units, and more broadly of the entire Prison Service, were not treated as the criticism of Prison Service. This is because of adopting a new type of approach which rejects the traditional view of conflict as something bad (Robbins 1998, 292). The adopted approach states that conflict should be accepted because it constitutes a kind of potential in the area of penitentiary dialogue, and allows for the transformation of the prison into a place where the socialisation of prisoners is carried out, so that after serving a sentence of imprisonment they can function well in the society, and prison and prisonization did not remain in their minds and everyday life.

\section{Re-education activities}

Conducting effective re-educational interactions requires activity both from the implementers of these activities and the prisoners themselves, who may be more or less ready to go through the change (Miller et al. 2015). Educators and psychologists aim to conduct re-education and therapeutic activities with prisoners, however, in many cases, due to, for instance, shortages in work places and staff shortages, prison staff are burdened with 
many other tasks, which means that instead of assistance and rehabilitation activities, they also have to deal with typically administrative and office tasks (Grzesiak 2014, 179-200). Officers are crammed into the roles of bureaucrats, people running errands, intermediaries and organizers, which is also noticeable in prisoners' letters when they comment on the work of officers, focusing on administrative and office matters related to satisfying specific needs of prisoners, such as the implementation of various requests, providing clothes, employment or receiving a positive assessment of the prisoner's progress in rehabilitation, e.g.

- 'I sincerely hope that on Monday the educator will chase the matter up with requests. I've asked for clothes and equipment, not a single one was found. So that I lie in someone else's clothes all day and read a book' (22);

- 'In December, the educator promised a 5-day pass. I will write you in the next letter when you write back if it worked. The work is to start next week, they said. A month of work in a jail, then a pass (paid). [...] You do not ask for a conditional early release, they write about it themselves' (9).

In addition, penitentiary educators are people who focus on the emotions of prisoners related to the execution of imprisonment, and most often them are negative. The negative emotions concern the burdensome areas of the penitentiary space related to their material and living situation, the way of resolving requests or relations in the cell where they are currently located, hence letters often contain regrets and complaints towards the refusal to fulfill their requests, or disappointment resulting from the timely handling of specific matters. For example, 'if you can, write me a few sentences I can use because we don't have a good educator here to understand such things. He completely blew up my targets [...]. Not only that, on the semi-annual commission he wrote that I was listening to music loudly [...]. What a defeat' (2). Basically, the expectations of prisoners towards penitentiary educators and the interactions they conduct are divergent.

Such opinions, assessments, feelings and emotions regarding the penitentiary space are transmitted by prisoners to the outside world via letters. This generates specific attitudes and expectations formulated by their relatives, which are often contrary to the facts and reality of the penitentiary. The educator does not decide on the resolution of requests, employment, passes or penitentiary policy of the institution, this is the responsibility of the head of the unit, who makes decisions on the evaluation of the prisoner's progress in rehabilitation, together with the penitentiary commission which takes into account the educator's opinion that does not have to be binding for the final settlement.

The prisoners' narratives describe the work of educators through the prism of what they can do for them - if nothing, they do not need it or it is ineffective, they are not respected. This is visible, for example, in the wording used by the prisoners in their correspondence, when the educators are called such names as: 'a tut (=tutor), a tutor, a reptile', but, on the other hand, the director of a penitentiary unit tends to be written with a capital letter, perhaps as an expression of respect or fear towards the person deciding about the prisoner.

The assessment of the 'usefulness' of the educator by the prisoner is essential for mutual cooperation or its lack. This may explain why the educational initiatives undertaken by the penitentiary staff, related to the implementation of rehabilitation penitentiary programmes, of course of contrasting qualities, meet different reactions from prisoners.

Many prisoners make pragmatic decisions to participate in the programmes as it gives them a chance to develop their interests, complete their education, gain a profession and employment, and often it also allows them to participate in activities organized and conducted by external entities and in a free environment, which gives them a chance to go outside the prison. For example: 'Now I go more outside the prison premises [...]. I have already been through the gate 12 times this year, and as you know, this is an argument for the judge and the prosecutor when I ask for the conditional release in my second year, I will not get it right away, but maybe in 2017 I will leave, the Director promised that he would apply for me, but for now I'm working and I'm not thinking about it, I'm just glad that I go outside the gate and I can break away from these walls at least a bit. Therefore, now I save every penny for each trip [...]. As you can see, I do not have enough time to write you a few words, when I come from work, I am tired, there are many of us, but only four are working and the rest 
pretend to be doing something [...]. I go to meetings, I do also a German course, and I still do origami, as you can see, I have a lot of work, so I don't have time after work, I just come to rest' (13). It can be assumed that basically any type of activity of prisoners in a penitentiary unit (school, courses, employment or any kind of therapeutic, re-education, readaptation and educational programmes) is for them a form of protection against prisonization and enslavement by the penitentiary space. Therefore, it is a manifestation of the prison pragmatism of prisoners, as participation in these types of activities increases the chances of obtaining passes or early release from imprisonment.

For these reasons, prisoners take up employment in penitentiary units or outside them, and if a given unit does not provide such an opportunity, they often request to be transported to a prison where they will be able to work. These threads also appear in the analysed correspondence of the prisoners, e.g.

- 'Anyway, I wanted to come here myself because of work, and I will be able to get a pass sooner and it is possible that I will also get the conditional release after I've served half of my sentence' (8);

- 'I'm fine, I work outside the prison from 8 am to 2 pm, I come in the afternoon, eat dinner and it's evening time, I do some exercise [...] it's not bad, just a bit more and I will have passes to go home' (16).

From the perspective of prisoners and their needs, the most beneficial means of penitentiary influence is employment, which gives them the opportunity to receive remuneration (in the case of paid work), stay in a free environment (in the case of work performed outside the prison), obtain additional award applications and a 'faster' expiry of the period of imprisonment filled with work.

Prisoners see multiplied benefits in various types of activities, programmes or employment, such as breaking the monotony of prison, doing something for themselves, investing in themselves and changing their life and situation, both in prison and after serving a prison sentence. Mastering a foreign language while in prison not only 'kills the time of imprisonment', but also offers new opportunities to find a job after leaving the penitentiary unit, especially since few units provide such an opportunity, hence the prisoners willingly use it as evidenced by the correspondence analysed, e.g.: 'In addition, I signed up for Italian and German' (17).

Therefore, the motivation of prisoners to participate in re-education programmes has various grounds. It may be caused by an instrumental and highly self-interested approach or by conscious and reflective participation in classes caused by the desire to change oneself and one's current life. It can also be assumed that many times all these motives occur simultaneously, but it is also true that participation in penitentiary interactions is treated primarily as a form of breaking the prison monotony and everyday routine.

From the perspective of the conducted penitentiary interactions, penitentiary rehabilitation programmes should be the most change-creating, unlike other measures of influence. An immanent feature of change is a positive or a negative value that is assigned to it. In the case of penitentiary programmes, the assessment or evaluation of the change that has occurred in the prisoner may be different for the prisoner and the penitentiary personnel. However, the internal motivation of the prisoner to participate in readaptation classes is most beneficial when it comes to social rehabilitation and the process of self-change. It is a difficult task for prisoners, because it involves a change in perceiving themselves and their life, it also requires evaluation of their current behaviour, insight into themselves, understanding and changing yourself, and transcendence towards other people or improvement of relations with the surroundings (the loved ones, society, environment). Participation in re-education classes may also be perceived by the inmates as a kind of risky task, because it is not known if and how they will deal with the situation of an intrapersonal and interpersonal conflict, hence the ambivalence of prisoners' attitudes during re-education classes is something typical, for example: 'I go to motherhood [=rehabilitation programme run by Prison Service] and the educator there asks you where your children are, your woman, he asks about everything and you must answer what and how in front of all 15 people from the penitentiary' (19).

Sometimes participation in certain classes or activities does not meet the expectations of prisoners, which may cause resistance and attempts to give up, for example: 'I am already in therapy. After more than a week of aging on a smelly adapter, no equipment, no clothes. [...]. Everyone praised the local gym ... I came to the ward, the 
gym is closed, renovation. And I don't get mad. There is nothing. It's good that the therapist has lent the radio because everything would probably blow up and I would come back [...] by fast train [...]. I don't feel like doing anything. I am depressed and angry. No one is there, it's cold and shit. It's all crap in these cells and it was supposed to be an Eldorado. If someone proposes a similar idea with a therapy, I'll fuck him... well, enough of my regrets' (22). The message of the letter is overwhelmingly negative; it radiates sadness, disappointment, a feeling of being deceived and a lack of motivation to continue therapeutic work. Of course, it can be assumed that such situations are incidental or that it is only a subjective assessment of the quality of penitentiary interactions, yet each one of them shows that convincing a prisoner to continue the therapy or to participate in other activities may be a challenge for the prison staff. In this context, the analysis of the prisoners' correspondence may be helpful in monitoring the activity of the prisoner during their re-education in order to be able to react to the current situation as adequately as possible.

\section{Conclusion}

The multi-factor determinism of efficiency causes difficulties in developing a tool that unambiguously states the change made in an individual, its origin, course and durability. This results in a constant need to search for clear and objective indicators that allow to capture this change in a particular individual. In this context, the analysis of prisoners' correspondence may be a new and valuable perspective, making their letters a source indicating the quality of the interactions carried out and their relevance to the rehabilitation needs of prisoners. It also constitutes a comparative assessment of the quality of the work of the Prison Service, which can be a source of criticism towards some of the prison problems perceived by prisoners, suggesting at the same time the existence of a 'hidden re-education programme' destabilizing the official assumptions of the undertaken changecreating activities. Thus, this article has indicated the educational references of the prisoners' correspondence and penitentiary space. Moreover, the penitentiary space contested by the prisoners has created the image of the prison in the eyes of the addressees of their correspondence.

Considering the experience of place by people serving a sentence, it should be emphasized that the penitentiary space should not be appropriated by only one group of people or by one dominant paradigm of influences (Stępniak, 2017). The natural implication of such a state of affairs should be the recognition, creation and modification of the penitentiary space so that it is most conducive to the rationalization and optimisation of penitentiary interactions. The trigger for this may be an in-depth analysis of the correspondence of prisoners, regarding the quality of penitentiary interactions, but also indicating areas requiring change or application of specific solutions on a larger scale.

\section{References}

Balawajder, K. 1992. Interpersonal conflicts: psychological analysis. Katowice: University of Silesia Publishing House.

Bernasiewicz, M. 2011. Symbolic interactionism in the theory and practice of social rehabilitation. Cracow: Impuls Publishing House.

Blumer, H. 2009. Symbolic interactionism. Perspective and method. Cracow: Nomos Publishing House.

Copik, I. 2013. "Place pedagogy - local culture and shaping the identity of a contemporary man." Scientific Works of The Jan Dlugosz Academy in Czestochowa 22: 179-189.

Fiske, J. 2009. Introduction to research on communication. Wroclaw: Astrum Publishing House.

Goban-Klas, T. 2009. Media and mass communication. Theories and analyzes of the press, radio, Internet television. Warsaw: Polish Scientific Publishers PWN.

Goffman, E. 2010. Framework analysis. Essay on the organization of experience. Cracow: Nomos Publishing House.

Goffman, E. 2011. Man in the theater of everyday life. Warsaw: Polish Scientific Publishers PWN.

Grzesiak, S. 2019. "Criminal recidivism prevention as a change management process in prison isolation conditions." In The contemporary dimension of public security. Shaping safe spaces, preventive actions, edited by Leszek Kołtun and Tomasz Kośmider, 50-67. Warsaw: Institute of Justice Press. 
Grzesiak, Sławomir. 2014. "Bureaucracy and bureaucratisation in the penitentiary work of educators." In Bright and shadows of contemporary penitentiary space. Man and the system, edited by Piotr Stępniak, 179-200. Kalisz-Poznan: Adam Mickiewicz University Publishing House.

Grzesiak, Sławomir. 2015. "Conflict and risk in the penitentiary work of educators." In Penitentiary social rehabilitation in interdisciplinary contexts, edited by Danuta Kowalczyk, Adam Szecówka and Sławomir Grzesiak, 140-157. Wroclaw: Atut Publishing House.

Kalisz, T. 2004. Employment of prisoners serving a sentence of imprisonment. Wroclaw: Cologne Limited Press.

Kalisz, T. 2011. "Comments on the purposes of imprisonment in the perspective of Art. 67 of the Executive Penal Code.” In The penalty of imprisonment and social readaptation of convicts, edited by Alicja Szerląg, 39-51. Wroclaw: Atut Publishing House.

Kalisz, T. 2015. "Classification decision. Legal nature and modes of control and verification." New Codification of Criminal Law 36: 67-82.

Kołtun, Leszek, and Tomasz Kośmider, ed. 2019. Contemporary dimension of public safety. Shaping secure areas, preventive actions. Warsaw: Institute of Justice Press.

Konopczyński, M. 2013. The crisis of rehabilitation or the success of apparent actions. Reflections on the Polish rehabilitation reality. Warsaw: Pedagogium Publishing House.

Kwieciński, Adam, and Tomasz Kalisz. 2013. „The goals of penitentiary isolation in the perspective of rejecting the idea of forced rehab." Acta Universitatis Wratislaviensis. Law and Administration Review 95: 117-129.

Lisowska-Magdziarz, M. 2004. Media content analysis. Guide for students. Cracow: Jagiellonian University Press.

Machel, H. 2003. Prison as a penal and rehabilitation institution. Gdansk: Arche Publishing House.

Mendel, M. 2006. Pedagogy of place. Wroclaw: Lower Silesian School of Higher Education TWP Scientific Publishing House.

Mendel, M. 2018. Pedagogy of place for common. City and school. Warsaw: Cathedral Scientific Publishing House.

Miller, W.R., Connors, G.J., DiClemente, C.C., Velasquez, M.M., and Donovan, D.M. 2015. Stages of change in addiction therapy. Choosing and planning an intervention. Cracow: Jagiellonian University Press.

Noise, E. 2006. Symbolic interactionism. Warsaw: Polish Scientific Publishers PWN.

Nowak, B.M. 2017. "The social climate of the institutional and family educational environment." Polish Journal of Social Rehabilitation 12: 105-117. doi:10.22432/pjsr.2016.12.08.

Ordinance of the Minister of Justice of 21 December 2016 on the organizational and order regulations for the execution of imprisonment, Journal of Laws of 2016, item 2231. Retrieved 3 June 2020 from http://isap.sejm.gov.pl/.

Ordinance of the Minister of Justice of 23 June 2015 on administrative activities related to the execution of pre-trial detention, penalties and coercive measures resulting in deprivation of liberty and the documentation of these activities, Journal of Laws of 2015 , item 927. Retrieved 3 Juni 2020 from http://isap.sejm.gov.pl/.

Palska, Hanna. 1999. "Social researcher towards the text. Some problems of qualitative analysis in sociology and literary theory." In $A$ look at the method. Studies in the methodology of sociological research, edited by Henryk Domański, Krystyna Lutyńska and Andrzej Rostocki, 161-176. Warsaw: IFiS PAN Publishing House.

Poklek, R. 2017. "Personal identification tests in penitentiary." Polish Journal of Social Rehabilitation 14: 41-57. doi: 10.22432/ pjsr.2017.14.04.

Przybysz, A. 2011. "Hidden agenda - content and review of selected empirical studies.” Pedagogical Review 1: 180-192.

Pytka, L. 2005. Pedagogy Rehabilitation. Selected theoretical, diagnostic and methodological issues. Warsaw: Academy of Special Education Publishing House.

Regulation of the Minister of Justice of 22 December 2016 on the organizational and order regulations for the execution of pre-trial detention, Journal of Laws of 2016, item 2290. Retrieved 3 Juni 2020 from http://isap.sejm.gov.pl/.

Robbins, S. 1998. Behavior in the organization. Warsaw: State Economic Publishing House.

Rogalski, M. 2016. Monitoring correspondence. Warsaw: C.H. Beck Press. 
Siemaszko, A. 1993. Tolerances. About theories of deviant behavior. Warsaw: Polish Scientific Publishers PWN.

Silverman, D. 2007. Interpretation of qualitative data. Methods of analyzing interview, text and interpretation. Warsaw: Polish Scientific Publishers PWN.

Stępniak, P. 2017. Rehabilitation (un)delusional. About the usurpation of penitentiary space. Warsaw: Difin Publishing House.

Szczepaniak, K. 2012. "Application of content analysis in the research of press articles - methodological reflections." Acta Universitatis Lodziensis Folia Sociologica 42: 83-112.

Szczepanik, R. 2015. Becoming a recidivist. Institutional careers of people returning to crime. Lodz: Lodz University Press.

Sztuka, M. 2013. Anachronism and topicality. The idea of rehabilitation in the dispute over modernity. Cracow: Jagiellonian University Press.

The Act of 6 June 1997 Executive Penal Code, Journal of Laws of 2020, item 523. Retrieved 3 Juni 2020 from http://isap.sejm.gov.pl/.

The Act of 6 June 1997 Executive Penal Code, Journal of Laws of 2019, item 1950. Retrieved 3 Juni 2020 from http://isap.sejm.gov.pl/.

Toporow, W. 2003. Space and thing. Cracow: Universitas Publishing House.

Slawomir GRZESIAK is the doctor of social sciences in the field of pedagogy, officer of the Prison Service. Pedagogue and administrativist, serving as an assistant professor at the Psychopedagogical Research Laboratory of the Research and Development Institute at the Academy of Justice. Research interests: rehabilitation and penitentiary pedagogy; social readaptation of convicts; organizational structure and functioning of the prison system in Poland; prison demographics.

ORCID ID: https://orcid.org/0000-0001-7701-9402 